İsletme Bilimi Dergisi 2019

Cilt:7 Sayı:3
SAKARYA

ÜN İVER SI TES II
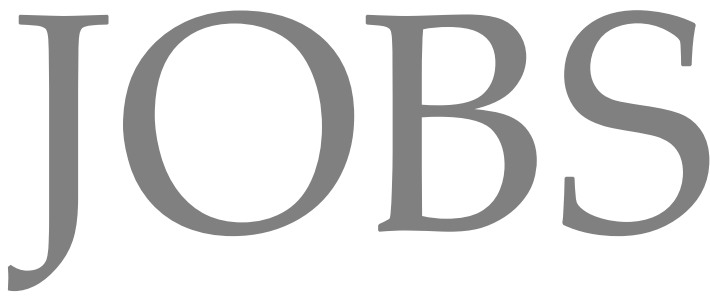

İşletme Bilimi Dergisi

The Journal of Business Science

Sakarya Üniversitesi / Sakarya University İşletme Fakültesi / Sakarya Business School

$\begin{array}{ll}\text { Cilt/Volume } & : 7 \\ \text { Say1/Issue } & : 3 \\ \text { Yil/Year } & : 2019\end{array}$

ISSN: 2148-0737

DOI: $10.22139 /$ jobs 
İşletme Bilimi Dergisi 2019 Cilt:7 Sayı:3
INNDEKS BILGILERI// INDEXING INFORMATION
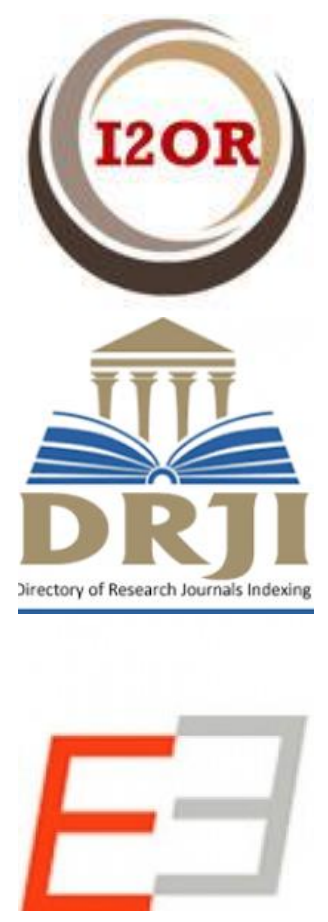

Akademilk Arasstrumadar Indeksi
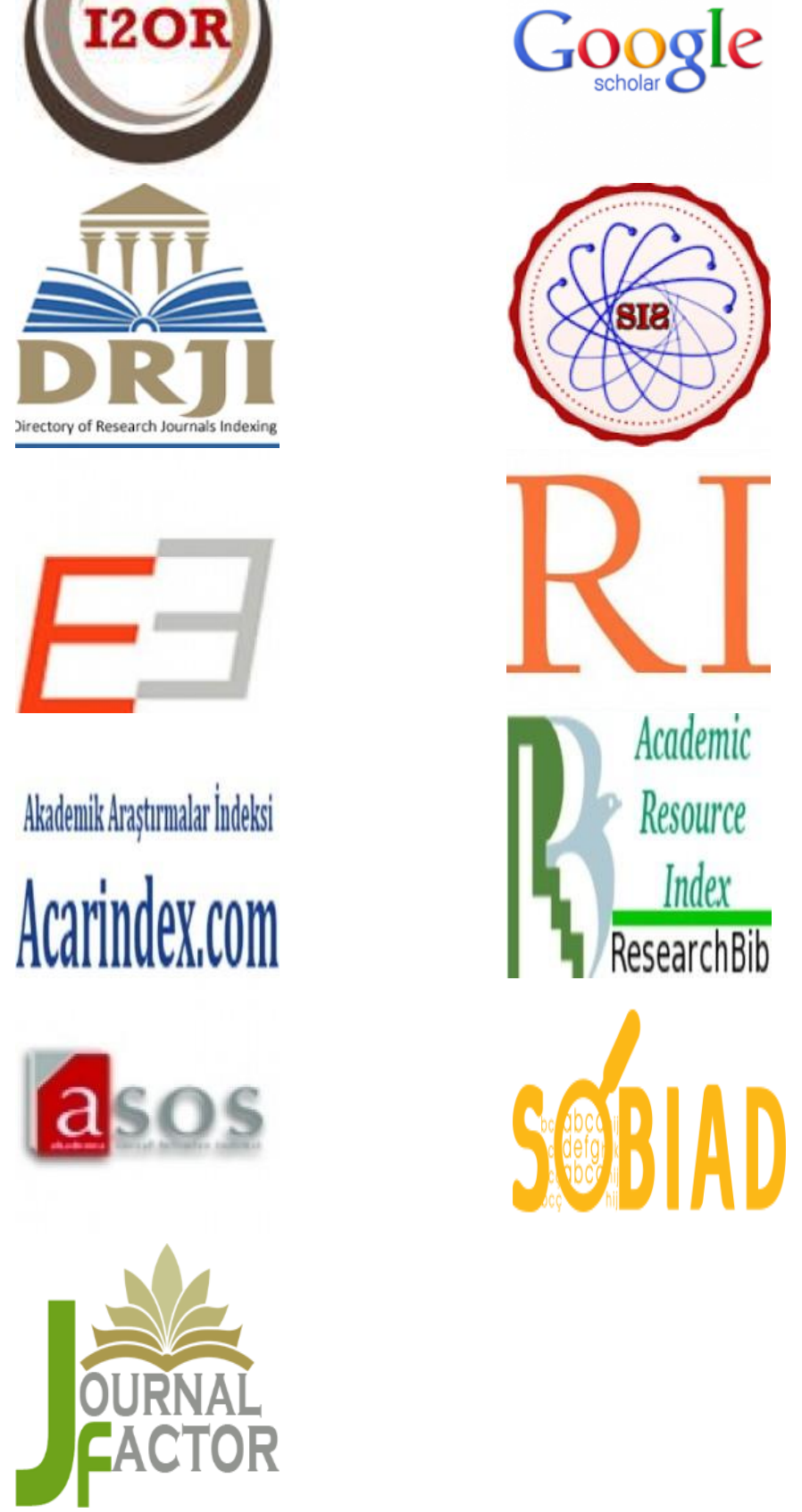
Kurucu Sahip/Founder

Işletme Bilimi Dergisi

2019

Prof. Dr. Gültekin YILDIZ

Imtiyaz Sahibi / Owner

Prof. Dr. Kadir ARDIÇ

Editör / Editor

Prof. Dr. Mahmut AKBOLAT

Editör Yardımcılarn / Assoc. Editors

Prof. Dr. Mustafa Cahit UNGAN

Mizanpaj Editörü / Layout Editor

Arş. Gör. Dr. Özgün ÜNAL

\section{Danışma Kurulu/Advisory Board}

Prof. Dr. Ahmet Vecdi CAN

Prof. Dr. Bülent SEZEN

Prof. Dr. Dilaver TENGILIMMOĞLU

Prof. Dr. Erman COŞKUN

Prof. Dr. Kadir ARDIÇ

Prof. Dr. Mehmet BARCA

Prof. Dr. Nihat ERDOĞMUŞ

Prof. Dr. Orhan BATMAN

Prof. Dr. Recai COŞKUN

Prof. Dr. Remzi ALTUNIŞIK

Prof. Dr. Selahattin KARABINAR

Prof. Dr. Sidıka KAYA

Prof. Dr. Şevki ÖZGENER

Prof. Dr. Türker BAŞ

Doç. Dr. Surendranath Rakesh JORY
Sakarya Üniversitesi

Gebze Yüksek Teknoloji Enstitüsü

Atılım Üniversitesi

İzmir Bakırçay Üniversitesi

Sakarya Üniversitesi

Ankara Sosyal Bilimler Üniversitesi

İstanbul Şehir Üniversitesi

Sakarya Üniversitesi

İzmir Bakırçay Üniversitesi

Sakarya Üniversitesi

İstanbul Üniversitesi

Hacettepe Üniversitesi

Nevşehir Üniversitesi

Galatasaray Üniversitesi

Southampton Üniversitesi 
Işletme Bilimi Dergisi

2019

Cilt:7 Sayı:3

It is assumed that the articles submitted for publication in our journal are written in ethical principles and the authors have obtained the necessary legal approvals from the relevant ethics committee. The responsibility of this matter belongs to the authors. Scientific responsibility for the articles belongs to the authors themselves. Published articles could be cited in other publications provided that fullreferenceisgiven.

İşletme Bilimi Dergisi; www.dergipark.gov.tr/jobs SakaryaÜniversitesi İşletme Fakültesi jobs@sakarya.edu.tr Esentepe Kampüsü 54187 Serdivan/SAKARYA

\author{
Prof. Dr. Kadir ARDIÇ \\ Prof. Dr. Mahmut AKBOLAT \\ Prof. Dr. Mustafa Cahid ÜNĞAN
}

Sekreterya / Secreteria

\author{
Arş. Gör. Dr. Özgün ÜNAL \\ Arş. Gör. Mustafa AMARAT \\ Arş. Gör. Ayhan DURMUŞ
}

Dergimize yayınlanmak üzere gönderilen makalelerin yazımında etik ilkelere uyulduğu ve yazarların ilgili etik kurulundan gerekli yasal onayları aldığı varsayılmaktadır. Bu konuda sorumluluk tamamen yazarlara aittir. İşletme Bilimi Dergisi'nde yer alan makalelerin bilimsel sorumluluğu yazara aittir. Yayınlanmış eserlerden kaynak gösterilmek suretiyle alıntı yapılabilir. 


\section{Bu Sayıda Katkıda Bulunan Hakemler}

\section{Reviewers List of This Issue}

Prof. Dr. Adnan Akın

Prof. Dr. Nilgün Sarıkaya

Prof. Dr. Ruziye Cop

Doç. Dr. Ali Taş

Doç. Dr. Buket Bora Semiz

Doç. Dr. Burcu Adıgüzel Mercangöz

Doç. Dr. Burhanettin Zengin

Doç. Dr. Emrah Özkul

Doç. Dr. Mahmut Hizıroğlu

Doç Dr. Mehmet Altınöz

Doç. Dr. Musa Said Döven

Dr. Öğr. Üyesi Abit Balın

Dr. Öğr. Üyesi Ebru Özlem Bilgin

Dr. Öğr. Üyesi Ersin Irk

Dr. Öğr. Üyesi Esra Dil

Dr. Öğr. Üyesi Gülcan Şantaş

Dr. Öğr. Üyesi Mustafa Yıldırım

Dr. Öğr. Üyesi Nurperihan Tosun

Dr. Öğr. Üyesi Onur Dirlik

Dr. Öğr. Üyesi Semih Okutan

Dr. Öğr. Üyesi Serkan Deniz
Kırıkkale Üniversitesi

Sakarya Üniversitesi

Abant İzzet Baysal Üniversitesi

Sakarya Üniversitesi

Bilecik Şeyh Edebali Üniversitesi

İstanbul Üniversitesi

Sakarya Uygulamalı Bilimler Üniversitesi

Karadeniz Teknik Üniversitesi

Ankara Sosyal Bilimler Üniversitesi

Havettepe Üniversitesi

Osmangazi Üniversitesi

İstanbul Üniversitesi

Sakarya Uygulamalı Bilimler Üniversitesi

Gaziosmanpaşa Üniversitesi

Sakarya Üniversitesi

Bozok Üniversitesi

Sakarya Üniversitesi

Cumhuriyet Üniversitesi

Osmangazi Üniversitesi

Sakarya Üniversitesi

Yalova Üniversitesi
İsletme Bilimi Dergisi 2019

Cilt:7 Sayı:3 
İşletme Bilimi Dergisi

2019

Cilt:7 Sayı:3
Değerli Bilim İnsanları,

İşletme Bilimi Dergisi Yayın Kurulu olarak 2019 son sayısı olan Cilt 7 Sayı 3 ile yayına çıkmanın gurur ve mutluluğu içerisindeyiz. Önceki sayılarımızda olduğ u gibi bu sayıda da farklı disiplinlerden gelen makaleler ile sizlere zengin bir içerik sunuyoruz.

Bu sayının ilk çalışması Nilgün SARIKAYA ve Remzi ALTUNIŞIK "Sağlık Kurumlarından Hizmet Alanlar Gözünden Hasta Hakları Konusundaki Uygulamalara Yönelik Tutum ve Değerlendirmeler" başlıkl çalışmadır. Yazarlar bu çalışmada hasta hakları konusunda halkın bilinç düzeyinin ve tutumalrının belirlenmesini amaçlamışlardır.

"Tüketicilerin Online Marka Topluluklarina Katilimlari Üzerinde Öz Benlik Uyumunun Rolü" başlıklı ikinci çalışmada, Sertaç ÇİFCI, Ruziye COP ve Ezgi GÖNENIR, öz benlik uyumu ile tüketicilerin online marka topluluklarma katılımları arasındaki ilişkiyi tartışmaktadırlar.

Üçüncü çalışma Ferda ALPER AY, İsmail ÜNALAN ve Özgün ÜNAL tarafından kaleme alınan "Üstler ve Astlar Arasındaki İletişimin Astların İş Tatmini Üzerindeki Etkisi" başlıklı çalışmadır. Bu makalede astlar ile üstler arasındaki iletişimin astların motivasyonunda nasıl bir etkiye sahip olduğu irdelenmiştir.

Dördüncü çalışmada Mehmet Yaşar, "Evaluation of the Competitive Factors Affecting Ticket Prices in Low-Cost Airlines" başlıklı çalışmasında düşük maliyetli havayolu işletmelerinin bilet fiyatlarının üzerinde etkisi olduğu varsayılan rekabetçi unsurların belirlenmesini amaçlamaktadır.

Bu sayının beşinci makalesi olan "Pozisyon Okulu mu, Kaynaklara Dayal Yaklaşım mı? Yöneticilerin Stratejik Konulara İlişkin Görüşleri Üzerine Nitel Bir Araştırma" başlıklı makale Recai COŞUN ve Duygu ÇIFTÇİ tarafından üst düzey yöneticilerin stratejik kararlarında Pozisyon Okulu ile Kaynaklara Dayal Yaklaşımın iddialarından hangilerine yakın durduklarım belirlemek amacıyla gerçekleştirilmiştir.

Sayımn son çalışmasını oluşturan "Turizmde Yeni Ürün Geliştirme ve Pazarlama Stratejileri: Kastamonu Destinasyonu Örneği" başlıklı makale, Nagehan BÜYÜKMEHMETOĞLU ve Kutay OKTAY tarafindan kaleme alınmıştır. Bu makalede yazarlar Kastamonu şehir merkezi destinasyonunda yeni ürün geliştirme ve pazarlama stratejilerinin neler olması gerektiŏini araştırmışlardır.

Dergimiz bu sayısı da işletmeciliğin farklı disiplinlerinde değerli bilim insanlarının kıymetli çalışmalarıyla zengin bir içerikle hazırlanmıştır. Dergi politikası olarak bundan sonraki sayılarımızda da işletme bilimine dayalı farkı disiplinlerden gelen çalışmaları yayınlamaya özen göstereceğiz. Bu sayımızda 
göndermiş oldukları makaleler ile dergimize katkı sağlayan tüm yazarlarımıza, dergimize gönderilen makalelerin değerlendirilmesi için kıymetli vakitlerini ayıran saygıdeğer hakemlerimize ve makalelerin dergide yayınlanmaya hazır hale gelmesi için yoğun bir gayret gösteren editör kurulumuz ve dergi sekretaryamıza teşekkürlerimi sunarım. Dergimizin okurlarımız ve bilim insanlarına faydalı olması dileklerimle sonraki sayılarımızda işletmeciliğin güncel çalışmaların bilim dünyasının hizmetine sunmak için siz değerli bilim insanları ve araştırmacıların katkıların bekliyoruz.
Işletme Bilimi Dergisi 2019 Cilt:7 Sayı:3

$$
\text { Saygılarımızla... }
$$

Prof. Dr. Mahmut AKBOLAT

Editör 
Işletme Bilimi Dergisi

2019

Cilt:7 Sayı:3

İÇİNDEKİLER/CONTENTS

Yil (Year) 2019 Cilt (Vol.) 7 Sayı (No) 3

\section{Araştırma Makaleleri/Research Articles}

Sağlık Kurumlarından Hizmet Alanlar Gözünden Hasta Hakları Konusundaki

Uygulamalara Yönelik Tutum ve Değerlendirmeler

Attıtudes and Evaluations of Service Receivers (Patients) of Health Institutions on Patient Rights

Practices

Prof. Dr. Nilgün SARIKAYA, Prof. Dr. Remzi ALTUNIŞIK

Tüketicilerin Online Marka Topluluklarına Katılımları Üzerinde Öz Benlik Uyumunun Rolü

The Role of Self-Congruence on Consumers' Participation in Online Brand Communities

Sertaç ÇIFCI, Ruziye COP, Ezgi GÖNENİR

Üstler ve Astlar Arasındaki İletişimin Astların İş Tatmini Üzerindeki Etkisi

The Effects of Communication between Superiors-Subordinates on Subordinates Job Satisfaction

Ferda Alper AY, İsmail ÜNALAN, Özqün ÜNAL

Düşük Maliyetli Havayolu İşletmelerinde Bilet Fiyatlarına Etki Eden Rekabetçi Unsurların Değerlendirilmesi

Evaluation of the Competitive Factors Affecting Ticket Prices in Low-Cost Airlines

Mehmet YAŞAR

Pozisyon Okulu mu, Kaynaklara Dayalı Yaklaşım mı? Yöneticilerin Stratejik Konulara İlişkin Görüşleri Üzerine Nitel Bir Araştırma

Positioning School or Resource-Based Approach? A Qualitative Research on the Managers' Views of

Strategic Issues

Recai COŞKUN, Duygu ÇiFTÇi

Turizmde Yeni Ürün Geliştirme ve Pazarlama Stratejileri: Kastamonu Destinasyonu Örneği

New Product Development and Marketing Strategies in Tourism: The Case of Kastamonu City Center Destination 


\section{EVALUATION OF THE COMPETITIVE FACTORS AFFECTING TICKET PRICES IN LOW-COST AIRLINES ${ }^{1}$}

\author{
Res. Ast. Mehmet YAŞAR \\ Kastamonu University, School of Civil Aviation, Aviation Management Department, \\ myasar@kastamonu.edu.tr \\ ORCID ID: orcid.org/0000-0001-7237-4069
}

\section{Evaluation of the Competitive Factors Affecting Ticket Prices in Low-Cost Airlines}

\begin{abstract}
Aim: This study was designed to determine the competitive elements that are thought to have an impact on the ticket prices of low-cost airlines.

Method: Using ticket prices from routes in which Pegasus Airlines operates, a model was formed to examine the relationship between ticket prices and a variety of variables including the monthly frequency of the routes, the monthly available seats, the market share on the route, whether it is a monopoly on the route or not, the number of airlines operating on that route, whether there is another low-cost carrier on that route as well as the level of concentration on the route. Linear regression analysis and T-Test were used to test the model and reveal the levels of difference. Findings: The study found that market share, the number of flights on the route and route concentration values had a significant positive effect on the ticket prices. On the other hand, the presence of another low-cost airline on the route has a negative effect on ticket prices. In addition, ticket prices were found to be higher in monopoly markets and in markets with only one low-cost airline.
\end{abstract}

Results: The research is important in terms of examining competitive effects on ticket prices.

Keywords: Ticket Prices, Competition, Regression, T-Test

\footnotetext{
1 This research was presented at the 2018 Business and Organization Research Conference and extended by the author after the conference.
} 
Evaluation of the

Competitive

Factors Affecting

Ticket Prices in

Low-Cost Airlines

596

\section{Düşük Maliyetli Havayolu İşletmelerinde Bilet Fiyatlarına Etki Eden Rekabetçi Unsurların Değerlendirilmesi}

\section{ÖZ}

Amaç: Bu araştırma düşük maliyetli havayolu işletmelerinin bilet fiyatlarının üzerinde etkisi olduğu düşünülen rekabetçi unsurların belirlenmesi amacıyla tasarlanmıştır.

Yöntem: Bu kapsamda Pegasus havayollarının seferlerini gerçekleştirdiği hatların bilet fiyatları elde edilmiş ve söz konusu hatlardaki aylık frekans, ay bazında arz edilen koltuk, hattaki pazar payı ve bununla ilgili olarak hattın monopol olup olmaması, o hatta faaliyet gösteren havayolu sayısı, ilgili hatta başka bir düşük maliyetli işletmenin olup olmaması ve hattın yoğunlaşma seviyesi gibi değişkenlerle bilet fiyatları arasındaki ilişkiyi incelemek üzere bir model kurulmuştur. Ayrıca monopol pazarlarda ve sadece tek bir düşük maliyetli havayolu işletmesinin var olduğu pazarlardaki fiyatların farklılıkları da araştırma kapsamında ele alınmıştır. Modelin test edilmesi ve farklılık düzeylerinin ortaya çıarılması için doğrusal regresyon analizi ve T-Testi kullanılmıştır.

Bulgular: Araştırma sonucunda havayolu işletmesinin pazar payının, ilgili hatta gerçekleştirdiği sefer sayısının ve hattın yoğunlaşma değerlerinin bilet fiyatları üzerinde anlamlı pozitif etkisinin olduğu, bir başka düşük maliyetli havayolu işletmesinin ilgili hatta mevcut olmasının bilet fiyatları üzerinde negatif etkisinin olduğu bulguları elde edilmiştir. Ek olarak, monopol pazarlarda ve sadece tek bir düşük maliyetli havayolu işletmesinin olduğu pazarlarda bilet fiyatlarının daha yüksek olduğu sonucuna ulaşılmıştır.

Sonuç: Araştırma bilet fiyatları üzerindeki rekabetçi etkilerin incelenmesi açısından önem arz etmektedir.

Anahtar Kelimeler: Bilet Fiyatları, Rekabet, Regresyon, T-Testi

\section{I.INTRODUCTION}

The liberalization tendencies, which first emerged in the United States (USA) and followed by Europe before moving to spread all over the world, brought a lot of innovations to the air transport industry. Access and entry to markets became easier and more comfortable after the liberalization movements. This ease brought a quantitative increase of businesses and prepared the ground for the emergence of new airlines (Fu et al., 2010; Dobruszkes, 2009).

The emergence of low-cost carriers (LCC) in the USA, the European Union countries, and almost all over the world today is considered to be the most important output of liberalization movements (Lawton, 2002). The LCC model emerged in North America under the leadership of Southwest airlines 
before being first adopted by other airlines in the region and then spread across the world (Graham and Shaw, 2008: 1440).

An examination of the Turkish aviation environment reveals that airlines, other than Turkish Airlines, are actively involved in the market, especially following the 2003 liberalization of domestic routes. This has led to an increase in demand, which translates to an increased number of passengers, and, an increased volume in both domestic and international routes for Turkish aviation sector (Battal et al., 2006). Before the liberalizations, the Turkish aviation sector only had Turkish airlines, which is a traditional airline and other airlines operating Charter flights. After the liberalizations, just as in the US, low-cost airlines following the cost leadership strategy emerged in the Turkish air transportation industry (Özsoy, 2010).

Data from the ministry of transport could be used to support the increase in the volume of the sector. Based on the 2017 report of the Ministry of Transport, a comparison of the 2003 and 2016 figures reveal that whereas the number of domestic passengers was 9.1 million in 2003, the number surpassed 100 million in 2016, reaching 102.4 million. The number of passengers on international routes, which was 25 million in 2003, reached 75 million at the end of 2016. In addition, the number of destinations flown also increased from 26 to 55 in domestic lines and from 60 to 286 in international flights (UDHB, 2017). Undoubtedly, the important reasons for this increase are the freedom of access to the market due to the liberalization and the emergence of the airline companies operating under new business models. As in other examples abroad, the airlines in Turkey which identify as LCC, have taken their place in the market and contributed to the growth of the aforementioned volumes.

According to ICAO's definitions, Low-Cost Airlines in Turkey include (ICAO, 2017):

$$
\begin{array}{ll}
\text { - } & \text { Atlas Global } \\
\text { - } & \text { Corendon } \\
\text { - } & \text { Onur Air } \\
\text { - } & \text { Pun Express* } \\
\hline
\end{array}
$$

LCCs aim to minimize their costs in all processes. In this context, they mostly use secondary airports. The reasons for this may include low turnaround times due to low density, fewer slot problems, inability to access primary airports or the stiff competition when they manage to enter these airports, and relatively low fees at secondary airports (Barbot, 2004: 2-3).
Evaluation of the Competitive

Factors Affecting

Ticket Prices in

Low-Cost Airlines 
İşletme Bilimi Dergisi (JOBS), 2019; 7(3): 595-610. DOI: 10.22139/jobs.525415

Evaluation of the

Competitive

Factors Affecting

Ticket Prices in

Low-Cost Airlines

598
Although included in the LCC list by ICAO, it may be difficult to consider LCCs such as Ryanair, Southwest and Wizz Air as 100\% LCC in the Turkish context given the airports they use, their fleet structures and their network structures. However, considering these features, Sun Express and Pegasus are the two closest airlines with LCC qualifications.

The increase in sector volume that resulted from the 2003 domestic liberalization in Turkey brought competition. This process, which was started with the increase in the number of flight points, also triggered an increase in the frequency at these points, leading to the possibility of more flight points and more journeys in both domestic and international routes. There is a need for the examination of the competitive status of the market given the increased number of destinations, the increased number of flights in these destinations as well as the presence of LCCs in these markets.

An examination of the competition dimension of air transport, especially on the domestic front, reveals that most studies have focused on market structures. Among these, Sarıbaş and Tekiner (2015) drew a general framework of airlines in Turkey, Kirac1 et al. (2017) examined the competitiveness of airlines at the airports by considering their market shares at those airports, and Yaşar and Gerede (2018) looked at the competitive status of markets with concentration criteria on the basis of city pair.

These studies are based on a 'general to specific' model, and all 3 of them reached the conclusion that the air transport market in Turkey is not truly competitive. In this study, we intended to evaluate the competitive features of ticket prices resulting from the internal dynamics of the airline as opposed to the inter-firm or market structure dimensions. In this context, 134 flight routes (origin-destination) of Pegasus airlines, which is identified as an LCC, were analyzed and the competitive factors that are thought to have an effect on ticket prices tested within the determined model.

\section{LITERATURE}

There are different studies that look at various aspects and features of ticket prices. Table 1 provides information about the studies obtained as a result of the literature review. 
Table 1.

List of Literature Review

\begin{tabular}{|c|c|c|c|c|c|}
\hline Author(s) & Year & Methodology & Focus & Variable(s) & Results \\
\hline Barbot & 2004 & Regression & $\begin{array}{l}42 \text { one-way flights } \\
\text { of Ryan Air (LCC } \\
\text { Carrier) }\end{array}$ & $\begin{array}{l}\text { D:Price } \\
\text { I:Market Share, Existence } \\
\text { of LCC, Number of } \\
\text { Competitors }\end{array}$ & $\begin{array}{l}\text { No Effect: Existence of } \\
\text { LCC } \\
\text { Positive } \\
\text { Number } \\
\text { Competitors } \\
\text { Negative } \\
\text { Market Share }\end{array}$ \\
\hline $\begin{array}{l}\text { Dresner } \\
\text { et.al. }\end{array}$ & 1996 & Regression & $\begin{array}{l}\text { Southwest Entry at } \\
\text { BWI Airport in } \\
1993\end{array}$ & $\begin{array}{l}\text { D: Yield, Passenger } \\
\text { Numbers } \\
\text { I: Distance, LCC, Slots, } \\
\text { Vacation, Income, } \\
\text { Population, Market } \\
\text { Concentration }\end{array}$ & $\begin{array}{l}{ }^{*} \text { Presence of LCC } \rightarrow \\
\text { Lower Yields } \\
\text { *Presence of LCC } \rightarrow \\
\text { Higher traffic levels }\end{array}$ \\
\hline Stavins & 2001 & Regression & $\begin{array}{l}{ }^{*} 12 \text { Different } \\
\text { Routes in the USA } \\
{ }^{*} \text { Relationship } \\
\text { between price } \\
\text { discrimination and } \\
\text { market } \\
\text { concentration }\end{array}$ & $\begin{array}{l}\text { D:Price Dispersion } \\
\text { I:Market Concentration, } \\
\text { Distance, Population, } \\
\text { Per-Capita Income, Ticket } \\
\text { Restrictions } \\
\text { DY:Touristic Traffic, Major } \\
\text { Hub, Landing Slots }\end{array}$ & $\begin{array}{l}\text { Price discrimination } \\
\text { increases when } \\
\text { markets become more } \\
\text { competitive }\end{array}$ \\
\hline $\begin{array}{c}\text { Gillen and } \\
\text { Morrison }\end{array}$ & 2003 & $\begin{array}{c}\text { Creating a } \\
\text { simple model }\end{array}$ & $\begin{array}{l}\text { Interaction } \\
\text { between full } \\
\text { service carriers } \\
\text { and LCC }\end{array}$ & $\begin{array}{l}\text { Dimensions:product } \\
\text { differentiation, bundling \& } \\
\text { integration between } \\
\text { airlines and airports. } \\
\text { D:Price }\end{array}$ & $\begin{array}{l}\text { FSC-LCC interaction } \\
\text { leads to price stability } \\
\text { and low price } \\
\text { dispersion. }\end{array}$ \\
\hline $\begin{array}{l}\text { Giaume } \\
\text { and } \\
\text { Guillou }\end{array}$ & 2004 & Regression & $\begin{array}{l}\text { *Ticket prices for } \\
\text { flights from Nice } \\
\text { Airport } \\
\text { *Price } \\
\text { discrimination and } \\
\text { market } \\
\text { concentration }\end{array}$ & $\begin{array}{l}\text { I:Ticket Restrictions, } \\
\text { Market Share, Distance, } \\
\text { Average Population, } \\
\text { Number of Days Before } \\
\text { Departure } \\
\text { DY: LCC, Hub Airport, } \\
\text { Oneway Ticket, Business } \\
\text { Class Ticket }\end{array}$ & $\begin{array}{l}{ }^{*} \text { Negative correlation } \\
\text { between price level } \\
\text { and concentration } \\
\text { and } \\
{ }^{*} \text { Concentration } \\
\text { positively affected the } \\
\text { airline ticket price } \\
\text { sensitivity. }\end{array}$ \\
\hline $\begin{array}{l}\text { Gerardi } \\
\text { and } \\
\text { Shapiro }\end{array}$ & 2009 & $\begin{array}{c}\text { Panel Data } \\
\text { Analysis }\end{array}$ & $\begin{array}{l}\text { Competition and } \\
\text { price dispersion } \\
\text { relationship } \\
\text { 1993-2006 period }\end{array}$ & $\begin{array}{l}\text { D:Price Dispersion } \\
\text { I:Market Share,HHI,Total } \\
\text { Flights, Tourist earnings } \\
\text { (related with } \\
\text { accomodation) } \\
\text { DY:Hub, Small City } \\
\text { Presence }\end{array}$ & $\begin{array}{l}\text { When competition } \\
\text { and number of } \\
\text { carriers } \uparrow \text {, } \\
\text { price dispersion and } \\
\text { prices } \downarrow\end{array}$ \\
\hline Orlov & 2011 & Regression & $\begin{array}{l}\text { Internet and price } \\
\text { dispersion } \\
\text { relationship }\end{array}$ & $\begin{array}{l}\text { D:Average Fare and Price } \\
\text { Dispersion } \\
\text { I:Market Share, Internet } \\
\text { Penetration, } \\
\text { DY: Monopoly, Duopoly } \\
\text { and Compete, Southwest } \\
\text { Presence, Direct Flights, } \\
\text { Peak Period }\end{array}$ & $\begin{array}{l}\text { *Internet has } \\
\text { influenced airline } \\
\text { competition. } \\
\text { (domestic routes) } \\
\text { *The effect of the } \\
\text { Internet on prices and } \\
\text { dispersion is larger } \\
\text { on direct flights than } \\
\text { indirect ones. }\end{array}$ \\
\hline
\end{tabular}

Evaluation of the Competitive Factors Affecting Ticket Prices in Low-Cost Airlines 599 
İşletme Bilimi Dergisi (JOBS), 2019; 7(3): 595-610. DOI: 10.22139/jobs.525415

Evaluation of the

Competitive

Factors Affecting

Ticket Prices in

Low-Cost Airlines

600

Table 1. Contuned

\begin{tabular}{|c|c|c|c|c|c|}
\hline Author(s) & Year & Methodology & Focus & Variable(s) & Results \\
\hline $\begin{array}{l}\text { Gaggero } \\
\text { and Piga }\end{array}$ & 2011 & $\begin{array}{c}\text { Panel Data } \\
\text { Analysis }\end{array}$ & $\begin{array}{l}{ }^{*} \text { Citypair markets } \\
\text { within UK-Ireland } \\
{ }^{*} \text { Market power \& } \\
\text { Price dispersion } \\
\text { relationship }\end{array}$ & $\begin{array}{l}\text { D:Gini Coefficient } \\
\text { I: HHI, Load Factor, } \\
\text { Total Flights, } \\
\text { Frequency, Departure } \\
\text { Time, Purpose } \\
\text { DY: Christimas, Easter, } \\
\text { Month }\end{array}$ & $\begin{array}{l}\text { *Negative relation } \\
\text { between competition } \\
\text { and price dispersion, } \\
{ }^{*} \text { Competition hinder } \\
\text { the airlines' ability to } \\
\text { price discriminate, } \\
\text { *This effect seems to be } \\
\text { reduced in peak } \\
\text { periods. }\end{array}$ \\
\hline
\end{tabular}

In one of the studies, Barbot (2004) analyzed 42 one-way flights by Ryan Air originating from Paris Beauvais, Brussels Charleroi, Dublin, London Stanstead and Milan Bergamo and found that the existence of another LCC on the routes had no effect on ticket prices, while the number of competitors on the routes had a positive effect on the ticket prices and the market share had a negative effect.

Dresner et al. (1996) investigated the effect of the entry of low-cost airlines into the market on airports and routes and found that the presence of LCCs had an average reduction effect of $38 \%$ on revenue. In a similar study, Stavins (2001) looked at the relationship between market concentration and different price applications on various routes within the USA. The findings show that as markets become more competitive, the price distribution attributed to ticket restrictions increases. Gillen and Morrison (2003) evaluated the competition between traditional carriers and low-cost carriers in terms of price and concluded that the interaction between these carriers brought price stability and relatively less price discrimination. Giaume and Guillou (2004) examined the relationship between price distribution and market concentration on Nice flights in the European market and found a negative correlation between the price level and concentration. They also concluded that concentration positively affected the airline ticket price sensitivity.

Gerardi and Shapiro (2009) examined the relationship between airline prices and the level of competition in the industry using panel data analysis covering the period of 1993-2006. The findings show that competition has a negative effect on price distribution. Orlov (2011) evaluated the ticket price distribution in airlines in terms of the effects of the internet and concluded that the internet reduced the average ticket price and increased the price distinction between firms. The study also concluded that the effect of the internet on ticket prices was higher on direct lines. Gaggero and Piga (2011) analyzed the flights between England and Ireland with 
regard to price distribution. They found that competition has an inverse relationship with a price distribution, that the level of price distribution decreases with increasing competition.

Considered as a whole, the studies in this area seemed to have generally examined diversification in ticket prices on the basis of airlines and market. In the studies reviewed above, Barbot (2004) 's research focused factors that were thought to affect the ticket pricing by airlines, including the number of competitors, the presence of another LCC and the market share. In this study, in addition to the variables used by Barbot, the concentration value of the route, whether the route is a monopoly or not, and the frequency of the airline operations in that route is added to the model. Moreover, tests were also conducted to check whether there is any differentiation in ticket prices for monopolistic routes and routes with only a single LCC. This is one of the dimensions in which this study intends to contribute to the literature.

\section{METHODOLOGY}

The aim of this study is to identify the competitive factors that are assumed to be the determinants of ticket prices in low-cost airlines and to examine how these factors affect prices. In this regard, we examined 134 flight routes in which Pegasus Airlines operate. After identifying the flight routes, variables that are thought to affect ticket prices were determined and a model was created. Hypotheses were determined within the model and their effects on ticket prices were tested within hypotheses.

The model created within the scope of the research is as follows:

$L_{C C} C_{p}=\beta_{1}$ SHAREpgs $_{i}+\beta_{2}$ NUMBERrival $_{i}+\beta_{3}$ FREQpgs $_{i}+\beta_{4} H H I_{i}+\beta_{5} L C C_{i}+\beta_{6}$ $M O N O_{i}$

$L C C_{p}=$ Ticket price per mile

$\beta_{1}$ SHAREpgs $_{i}=$ Pegasus airline's market share in the $i$ route

$\beta_{2}$ NUMBERrival ${ }_{i}=$ number of competitors on the $i$ route

$\beta_{3}$ FREQpgs $s_{i}=$ Pegasus airline's monthly frequency in route $i$

$\beta_{4} H_{H} I_{i}=$ Herfindahl-Hirscmann Index value on route $i$

$\beta_{5} L C C_{i}=$ Other LCCs except for Pegasus airline in route $i$ (if there is 1 , otherwise 0 )

$\beta_{6} M O N O_{i}=i$ route is monopoly (if monopoly is 1 , if not 0 )

Figure 1 shows the visual representation of the model.
Evaluation of the Competitive

Factors Affecting

Ticket Prices in

Low-Cost Airlines

601 
Evaluation of the

Competitive

Factors Affecting

Ticket Prices in

Low-Cost Airlines

602

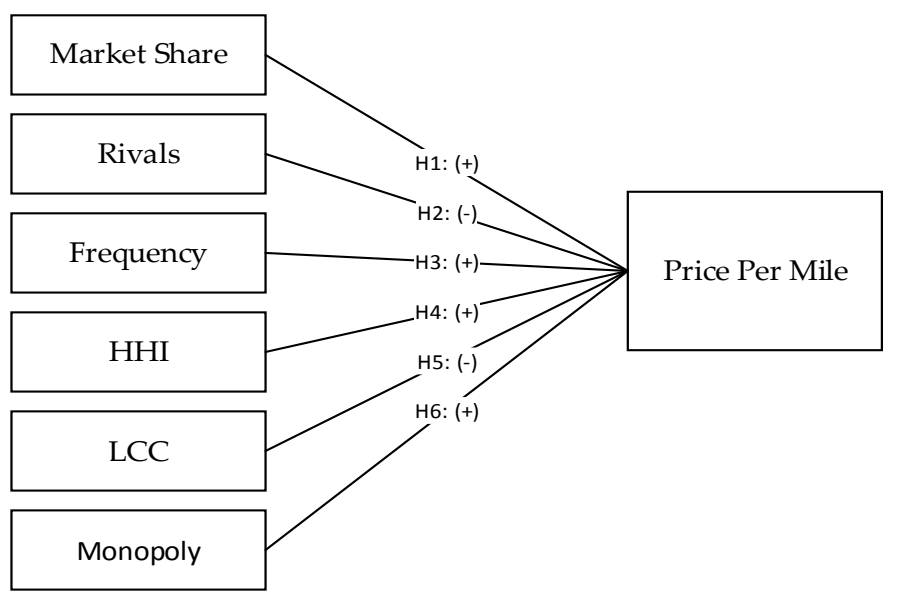

Figure 1.

Research Model

Data on the ticket prices used as the dependent variable in the model were obtained from the website of the airline. Anticipatory 'regular price' of the same day were used while obtaining the data. Special offers and flexible prices were not included in the dataset. Of the two prices not included, airlines have specific quotas on offer prices within their flights and flexible prices are a less preferred ticket price class considering the business model of Pegasus airlines. For the aforementioned reasons, these two price types were excluded. Ticket prices are considered as the ticket price per mile and it is intended to omit the relationship between flight distance and ticket price. There is no doubt that ticket price increases with an increase in distance. In order to eliminate this effect, ticket prices for each flight route were divided by the distance of that route and the price per mile was obtained as the dependent variable.

The market share which is one of the independent variables of the study was obtained by dividing the number of seats of each airline by the total supply for the specific route and the market share was obtained separately for each airline and for each flight route.

The variable for the number of competitors represents the number of airlines operating on the route. The frequency variable is the number of monthly trips and $\mathrm{HHI}$ variable represents the concentration value obtained by the sum of the squares of the market shares on each route. The $L C C_{i}$ and $M O N O_{i}$ variables are dummy independent variables which are represented by 1 if there is another low-cost airline on the line, otherwise, 0 , and 1 if the route is a monopoly, otherwise 0 respectively.

Linear regression analysis was used to test the model. The hypotheses tested within the scope of the research are as follows: 
H1: As the market share of the airline increases, prices increase.

$\mathrm{H} 2$ : As the number of competitors on the route increases, prices decrease.

H3: As the frequency of airline in the related route increases, ticket prices increase

H4: As the HHI value of the route increases, so does the ticket price.

H5: Prices are relatively low if there is another LCC on the route in which the airline operates

H6: If the airline is alone on that route, the prices are higher than those routes that are not monopolized.

\section{ANALYSIS}

In the analysis, T-test is used to determine whether or not monopolized markets create a price difference, and whether there is a difference in price in a market with more than one LCC in the market. Linear regression analysis was used to test the model given in the previous section. Table 2 and 3 show descriptive statistical data and T-Test results on monopoly and non-monopoly markets.

Table 2.

Descriptive Statistics for Monopoly and Non-Monopoly Markets

\begin{tabular}{llllll}
\hline \multicolumn{7}{c}{ Group Statistics } \\
\hline & Markets are & N & Mean & $\begin{array}{l}\text { Std. } \\
\text { Deviation }\end{array}$ & $\begin{array}{l}\text { Std.Error } \\
\text { Mean }\end{array}$ \\
\hline farepermile & Monopoly & 66 & 10,87445 & 7,290953 &, 897454 \\
& Not Monopoly & 68 & 7,87871 & 4,571629 &, 554391 \\
\hline
\end{tabular}

As seen in Table 2, 66 of the 134 markets examined are a monopoly while the remaining 68 are non-monopoly markets. In other words, Pegasus operates alone in almost half of the markets it operates. In Monopoly markets, the average ticket price per mile is $\$ 10.8$, while in other markets it is $\$ 7.87$. This implies that ticket prices are higher in monopoly markets than non-monopoly markets. Table 3 presents the results of the T-Test, which tests the statistical significance of the ticket price difference of the markets in question.
Evaluation of the Competitive

Factors Affecting

Ticket Prices in

Low-Cost Airlines

603 
İşletme Bilimi Dergisi (JOBS), 2019; 7(3): 595-610. DOI: 10.22139/jobs.525415

Evaluation of the

Competitive

Factors Affecting

Ticket Prices in

Low-Cost Airlines

604
Table 3.

Independent Groups T-Test Results (Monopoly Markets)

\begin{tabular}{|c|c|c|c|c|c|c|c|c|c|c|}
\hline \multicolumn{11}{|c|}{ Independent Samples Test } \\
\hline & & \multicolumn{2}{|c|}{$\begin{array}{l}\text { Levene's Test } \\
\text { for Equality of } \\
\text { Variances }\end{array}$} & \multicolumn{7}{|c|}{ T-test for Equality of Means } \\
\hline & & \multirow[t]{2}{*}{$F$} & \multirow[t]{2}{*}{ Sig. } & \multirow[t]{2}{*}{$t$} & \multirow[t]{2}{*}{ df. } & \multirow[t]{2}{*}{$\begin{array}{l}\text { Sig. (2- } \\
\text { tailed) }\end{array}$} & \multirow[t]{2}{*}{$\begin{array}{l}\text { Mean } \\
\text { Dif. }\end{array}$} & \multirow[t]{2}{*}{$\begin{array}{l}\text { Std. } \\
\text { Error } \\
\text { Dif. }\end{array}$} & \multicolumn{2}{|c|}{$\begin{array}{c}95 \% \\
\text { Confidence } \\
\text { Interval of the } \\
\text { Difference }\end{array}$} \\
\hline & & & & & & & & & Lower & Upper \\
\hline \multirow{3}{*}{$\begin{array}{l}\text { Fare } \\
\text { Per } \\
\text { mile }\end{array}$} & Equal & 6,644 & ,011 & 2,859 & 132 & ,005 & 2,9957 & 1,0479 & 9227 & 5,0687 \\
\hline & $\begin{array}{l}\text { variances } \\
\text { assumed }\end{array}$ & & & & & & & & & \\
\hline & $\begin{array}{c}\text { Equal } \\
\text { variances not } \\
\text { assumed }\end{array}$ & & & 2,840 & 108,715 & ,005 & 2,9957 & 1,0548 & 9049 & 5,0865 \\
\hline
\end{tabular}

According to the results of the T-test conducted to find out whether the price difference between monopoly and non-monopoly markets is significant, the average price per mile in monopoly markets (Avg $=10,87$; SE $=0.897$ ) and the average price per mile in non-monopoly markets (Avg $=7$, $87)$; $\mathrm{SE}=0.554)$ were found to be different from each other, and this difference is statistically significant $(t(108,71)=2.840 ; p<0.05)$.

Tables 4 and 5 show descriptive statistical data and T-Test results for markets where a single and more than one LCC exists.

Table 4.

Descriptive Statistics On the Status of Multiple LCCs in the Market

\begin{tabular}{|c|c|c|c|c|c|}
\hline \multicolumn{6}{|c|}{ Group Statistics } \\
\hline & LCC & $\mathbf{N}$ & Mean & Std. Deviation & $\begin{array}{l}\text { Std. Error } \\
\text { Mean }\end{array}$ \\
\hline farepermile & Exist & 37 & 6,35714 & 2,843977 & ,467547 \\
\hline & Not & 97 & 10,49744 & 6,774517 & 687848 \\
\hline
\end{tabular}

In Table 4, there is another LCC in 37 out of the 134 markets examined and there are no LCCs other than Pegasus in the remaining 97 markets. As will be remembered from Table 2, Pegasus has a monopoly in its 66 markets. Back to Table 4, in 31 out of the 97 markets where no other LCC exists, there is an airline that is classified as Charter or Traditional airline. In the markets where there is another LCC other than Pegasus, the average price per mile is $\$ 6.35$. In the markets where Pegasus airlines is the only operator, the average price per mile is $\$ 10.49$. Table 5 shows the T-Test results which test the statistical significance of the ticket price difference of the mentioned markets. 
Table 5.

T-Test Results of Independent Groups (LCC)

\begin{tabular}{|c|c|c|c|c|c|c|c|c|c|c|}
\hline \multicolumn{11}{|c|}{ Independent Samples Test } \\
\hline & & \multicolumn{2}{|c|}{$\begin{array}{l}\text { Levene's Test } \\
\text { for Equality of } \\
\text { Variances }\end{array}$} & \multicolumn{7}{|c|}{ T-test for Equality of Means } \\
\hline & & \multirow[t]{2}{*}{$\mathbf{F}$} & \multirow[t]{2}{*}{ Sig. } & \multirow[t]{2}{*}{$t$} & \multirow[t]{2}{*}{ df } & \multirow[t]{2}{*}{$\begin{array}{l}\text { Sig. (2- } \\
\text { tailed) }\end{array}$} & \multirow[t]{2}{*}{$\begin{array}{l}\text { Mean } \\
\text { Dif. }\end{array}$} & \multirow[t]{2}{*}{$\begin{array}{l}\text { Std. } \\
\text { Error } \\
\text { Dif. }\end{array}$} & \multicolumn{2}{|c|}{$\begin{array}{l}95 \% \text { Confidence } \\
\text { Interval of the } \\
\text { Difference }\end{array}$} \\
\hline & & & & & & & & & Lower & Upper \\
\hline \multirow{2}{*}{$\begin{array}{l}\text { Fare } \\
\text { Per } \\
\text { mile }\end{array}$} & $\begin{array}{c}\text { Equal } \\
\text { variances } \\
\text { assumed }\end{array}$ & 11,415 &, 001 & $-3,592$ & 132 & ,000 & $-4,1403$ & 1,152628 & $-6,4203$ & 1,8602 \\
\hline & $\begin{array}{c}\text { Equal } \\
\text { variances not } \\
\text { assumed } \\
\end{array}$ & & & $-4,978$ & 130,76 & , 000 & $-4,1403$ & ,831706 & $-5,7856$ & $-2,4949$ \\
\hline
\end{tabular}

According to the T-test results (in table 5) which was intended to find out whether there were more than one LCCs or not and whether the price difference in such a case significant or not, the average price per mile in the markets where Pegasus is the only LCC (mean $=10,49 ; \mathrm{SH}=0.687$ ) and the average price per mile in the markets where there is another $\mathrm{LCC}(\mathrm{L}=6,35$; $\mathrm{SH}=0,467)$ are different, and this difference is statistically significant $(\mathrm{t}(130$, $76)=-4,978 ; \mathrm{p}<0,05)$. This means that when there is another LCC in Pegasus market, the prices are relatively low.

The findings of the regression analysis conducted to test the operability of the model tested in the research are given in Table 6.

Table 6.

Regression Analysis Results

\begin{tabular}{lc}
\hline Variables & $\begin{array}{c}\text { Coefficients } \\
\text { (Standart Errors) }\end{array}$ \\
\hline Constant & $-2,155$ \\
Market Share &, $307^{*}$ \\
Competitor Number & $(, 158)$ \\
&, 691 \\
Frequency & $(, 500)$ \\
&, $119^{*}$ \\
HHI & $(, 062)$ \\
&, $741^{*}$ \\
LCC & $(, 446)$ \\
&,$- 189^{* *}$ \\
Monopoly $\quad(, 059)$ \\
Dependent Variable: Price Per Mile \\
$R^{2}$ &,- 012 \\
Adjusted $R^{2} \quad=, 187$ & $(, 137)$ \\
${ }^{*} \mathrm{p}<0.10 ; *$ p $<0.001$ & \\
Durbin Watson : 1,887 & \\
Number of Observations=134 & \\
\hline
\end{tabular}

Evaluation of the Competitive

Factors Affecting

Ticket Prices in

Low-Cost Airlines

605 
Evaluation of the

Competitive

Factors Affecting

Ticket Prices in

Low-Cost Airlines

606
According to the results of the regression analysis in Table 6, the adjusted $R^{2}$ value of the model is (.187) and the independent variables in the model explain $18 \%$ of the dependent variable. The Durbin Watson value is 1.887 and it is close to the values required in order to avoid autocorrelation.

Looking at the factors affecting the ticket price per mile, the market share was observed to have a significant effect at (.307). In other words, the market share has an increasing effect on the ticket price. Considering the dynamics of the sector, airlines were found to generally keep their ticket prices at higher levels in routes where they have high market shares. In this context, the presence of this significant effect shows that there is a consistent result considering the nature of air transport.

The effect of frequency and HHI on price per mile are significant (.119) and (.741) respectively. The increase in frequency provides an important premise on which the airline can increase its market share or on which to base its current high market share. The increase in frequency has an important role in the tariff-based components of service delivery, and a higher frequency airline is more attractive to passengers in terms of meeting the origin-destination transportation requirement within the minimum time (Gerede and Yalçınkaya, 2015: 124). It is, therefore, possible to find that the ticket prices are relatively higher in route where the frequency is higher. As it will be remembered, HHI gives some clues about the competitive structure of the route. The higher HHI value, the lower the competition level of the route. This implies that an airline will be able to maintain control of the ticket prices on the non-competitive route, and the possible result in this is that the ticket prices will be relatively high.

A significant negative effect (.189) is observed in the LCC dummy variable. LCCs try to minimize costs in all processes by following the cost leadership strategy and reflect this in their prices, and they seek to attain a competitive advantage by keeping ticket prices lower than traditional airlines. It is thus inevitable that having a second LCC on a route where there is already an LCC will have a reducing effect on ticket prices. The findings of the study support these hypotheses.

The number of competitors and the monopoly dummy variable have no significant effect on the price per mile. Given the competitive dynamics in air transport, the number of competitors is expected to have an impact on ticket prices. However, it was observed that the number of competitors did not have an effect on ticket prices within the model used in this study. Despite this, the significant effect of HHI, LCC and market share variables in the model indicates that the number of competitors has an indirect effect on 
the ticket prices. It was also observed that within the model of the study, whether the market is a monopoly or not doesn't have any significant effect. In the T-tests performed before the model, there was a significant difference of approximately $\$ 3$ per mile in the average ticket prices between monopoly markets and non-monopoly markets, but this effect was not found to hold within the model.

In light of all these data, the validation status of the hypotheses is given in Table 7.

Table 7.

\begin{tabular}{ccc}
\multicolumn{3}{c}{ Verification of Hypotheses } \\
\hline Hypotheses & Accept & Reject \\
\hline H1 & $X$ & \\
H2 & & $X$ \\
H3 & $X$ & \\
H4 & $X$ & \\
H5 & $X$ & \\
H6 & & $X$ \\
\hline
\end{tabular}

The data in Table 7 shows the confirmation of hypotheses H1, H3, H4 and H5. In other words, increasing market share of the airline has an increasing effect on ticket prices; the ticket prices increase as the concentration of the route increases i.e. as the competition reduces in the route; ticket price increase as the number of flights performed by the airline on the route increases; the ticket price decreases if there is more than one LCC on the route. No significant effect was observed with respect to the number of competitors and whether the route is a monopoly or not.

\section{CONCLUSION}

This study sought to evaluate the competition in the air transport market in light of the ticket prices as well as examine the competitive factors that are thought to have an impact on ticket prices, which is among the most important competition tools for airlines. The results of the study show that market share has a significant effect on airline ticket prices and this effect is positive. In other words, as the airline's market share in the relevant route increases, the ticket price on that route also increases. This finding is consistent with the characteristics of the sector. If an airline is established in the market, it gets to be dominant in that market dominance and the increased market share is reflected in the ticket prices. Looked at from
Evaluation of the Competitive

Factors Affecting

Ticket Prices in

Low-Cost Airlines

607 
Evaluation of the

Competitive

Factors Affecting

Ticket Prices in

Low-Cost Airlines

608 another perspective, an airline with a lower market share getting into the market with higher prices may lag a few steps behind the competition.

As the frequency of the airlines increases, so does the ticket price. An increase in frequency parallel to the market share leads to more trips and more supply in the relevant market. In line with the characteristics of the tariff-based components of service delivery, passengers are expected to choose the airline with a higher frequency in order to minimize the time between the actual origin and the actual destination points. In this context, the price increase arising from the frequency increase is natural considering the characteristics of the sector, and it shows the consistency of the research findings and the characteristics of the sector.

Another factor dealt with in the study was the relationship between the concentration level of the route and the ticket price. Concentration value also has a significant positive effect on ticket prices. Concentration is inversely proportional to competition and if concentration increases, competition in the relevant market decreases. In this sense, when the concentration value is high, the relevant ticket price is expected to be high and the findings of this study support this.

If there is another LCC on the route, ticket prices decrease. LCCs are companies that sell tickets at a lower price than their competitors and keep costs of the operations and processes at a minimum level. For this reason, the second LCC in a market where one is already operating will have reducing effect on ticket prices. The findings of the research are consistent with this and support this position.

No significant relationship was found between the number of competitors and the monopoly status of the airlines and the ticket prices. However, the T-Test analyzes conducted outside the model revealed that ticket prices were different in monopoly and non-monopoly markets, and this difference was significant.

Many studies exist in the literature on the determinants of ticket prices. This study examined the determinants of ticket prices for low-cost airlines by considering the competitive factors alongside the factors commonly studied in the literature. In this context, this research is important in terms of determining the effects of competition factors on ticket prices. Future studies could include different components which are likely to affect competition in the model and increase the number of routes and the number of airlines. 


\section{REFERENCES}

Barbot, C. (2004). Low cost carriers, secondary airports and State aid: an economic assessment of the Charleroi affair. Faculdade de Economia, Universidade do Porto.

Battal, Ü., Yılmaz, H., and Ateş, S. S. (2006). Türkiye'de İç Hatlarda Serbestleşme ve Geleceği. In Conference Paper Presented on Kayseri VI. Havacilık Sempozyumu.

Dobruszkes, F. (2009). Does liberalisation of air transport imply increasing competition? Lessons from the European case. Transport Policy, 16(1): 29-39.

Dresner, M., Lin, J., and Windle, R. (1996). The Impact of Low-Cost Carriers on Airport and Route Competition. Journal of Transport Economics and Policy, 30(3): 309-328. Retrieved from http://www.jstor.org/stable/20053709

Fu, X., Oum, T. H., and Zhang, A. (2010). Air transport liberalization and its impacts on airline competition and air passenger traffic. Transportation Journal, 24-41.

Gaggero, A. A., and Piga, C. A. (2011). Airline market power and intertemporal price dispersion. The Journal of Industrial Economics, 59(4): 552-577.

Gerardi, K. S., and Shapiro, A. H. (2009). Does competition reduce price dispersion? New evidence from the airline industry. Journal of Political Economy, 117(1): 137.

Gerede, E., and Yalçınkaya, A. (2015). Ekonomik Düzenlemelerin Havayolu Yönetimine Etkisi. E. Gerede in, Havayolu taşımacıllğı ve ekonomik düzenlemeler teori ve Türkiye uygulaması (s. 119-162). Ankara: Sivil Havacılık Genel Müdürlüğü Yayınları.

Giaume, S., and Guillou, S. (2004). Price discrimination and concentration in European airline markets. Journal of Air Transport Management, 10(5): 305-310.

Gillen, D., and Morrison, W. (2003). Bundling, integration and the delivered price of air travel: are low cost carriers full service competitors? Journal of Air Transport Management, 9(1): 15-23.

Graham, B., and Shaw, J. (2008). Low-cost airlines in Europe: Reconciling liberalization and sustainability. Geoforum, 39(3): 1439-1451.

ICAO (2017). https://www.icao.int/sustainability/Documents/LCC-List.pdf

Kiracı, K., Yaşar, M., Kayhan, S., and Ustaömer, T. C. (2017). Türkiye İç Hat Hava Taşımacılığı Üzerine Herfindahl-Hirshman Endeksi ve CRm Yoğunlaşma Oranı Analizi ile Piyasa Yoğunlaşmasının Tespit Edilmesi. Gaziantep University Journal of Social Sciences, 16(3): 687-704.

Lawton, T.C., 2002. Cleared for Take-off: Structure and Strategy in the Low Fare Airline Business. Ashgate, Aldershot.
Evaluation of the

Competitive

Factors Affecting

Ticket Prices in

Low-Cost Airlines

609 
İşletme Bilimi Dergisi (JOBS), 2019; 7(3): 595-610. DOI: 10.22139/jobs.525415

Evaluation of the Özsoy, G. (2010). Türk Havayolu İşletmelerinin 2003 İç Hat Serbestleşmesine

Competitive

Factors Affecting

Ticket Prices in

Low-Cost Airlines

610
Verdikleri Stratejik Tepkiler, Yayınlanmamış Yüksek Lisans Tezi, Anadolu Üniversitesi Sosyal Bilimleri Enstitüsü, Eskişehir.

Saribas, H., and Tekiner, I. (2015). Türkiye Sivil Havacilik Sektöründe Yogunlasma/Concentration in Turkish Civil Aviation Market. Finans Politik \& Ekonomik Yorumlar, 52(610): 21.

Stavins, J. (2001). Price discrimination in the airline market: The effect of market concentration. Review of Economics and Statistics, 83(1): 200-202.

UDHB. (2017). Havacillk ve Uzay Teknolojileri. Ankara: UDHB. Available at: http://www.udhb.gov.tr/images/faaliyet/a5ec26a31a72281.pdf

Yaşar, M., and Gerede, E. (2018). Türkiye Havayolu İç Hat Şehir Çiftlerindeki Pazar Yapılarının Piyasa Yoğunlaşması Ölçütleri ile Belirlenmesi. Yönetim ve Ekonomi, 25(1): 171-197. 